\title{
STRATEGIES USED BY LECTURERS IN TEACHING ENGLISH PRODUCTIVE SKILLS AT ENGLISH STUDY PROGRAM OF FKIP UIR
}

\author{
Muhammad Ilyas \\ Universitas Islam Riau \\ email:m.ilyas29@edu.uir.ac.id
}

\begin{abstract}
Teaching English productive skills was considered to become the most difficult lesson, the students needed to have good pronunciation, master structure, discourse and the social context of cultural competence. Besides, speaking and writing were difficult, more effort was required on the part of the students and lecturers. It was not enough for the students to listen only. This research tried to explore the strategies used by the lecturers and their influences in developing students' cognitive academic language proficiency by working on students' English productive skills. This research was a descriptive qualitative research. It consisted of only one variable, which the researcher wanted to explore the description of strategies used by the lecturers and their influences on students' English productive skills at English study program of FKIP UIR. In this research, researcher only focused on exploring the strategies used by the lecturers and describing the influences from those strategies on students' English productive skills. The result of this research showed that there were some strategies used by lecturers in teaching English productive skills at English study program of FKIP UIR, they were: (1) in the speaking classroom; Buzz group, think-pair-share, circle of voices, video recording method. (2) in the Writing classroom; collaborative writing technique. All of those strategies were suitable for teaching speaking or writing and gave description for reader to increase students' English productive skills.
\end{abstract}

Key Words: Teaching Strategy, English Productive Skills

\section{STRATEGI YANG DIGUNAKAN OLEH DOSEN DALAM MENGAJAR KETERAMPILAN PRODUKTIF BAHASA INGGRIS DI PROGRAM STUDI PENDIDIKAN BAHASA INGGRIS, FKIP UIR}

\begin{abstract}
Abstrak
Mengajar keterampilan produktif dalam bahasa Inggris dianggap menjadi pelajaran yang paling sulit, para siswa perlu menguasai pengucapan, struktur, wacana dan konteks sosial kompetensi budaya. Selain itu, berbicara dan menulis itu memang sulit dan banyak usaha yang dibutuhkan oleh para siswa dan dosen karena tidak cukup bagi siswa untuk mendengarkan saja. Penelitian ini mencoba mengeksplorasi strategi yang digunakan oleh dosen dan pengaruhnya dalam mengembangkan kemampuan kognitif akademis bahasa siswa dengan cara mengolah keterampilan produktif bahasa Inggris siswa. Penelitian ini merupakan penelitian deskriptif kualitatif. terdiri dari satu variabel, dimana peneliti ingin
\end{abstract}


mengeksplorasi strategi yang digunakan oleh dosen dan pengaruhnya terhadap keterampilan produktif bahasa Inggris siswa pada program studi pendidikan bahasa Inggris FKIP UIR. Dalam penelitian ini, peneliti hanya berfokus pada deskripsi strategi yang digunakan oleh dosen dan menggambarkan pengaruh dari strategi tersebut terhadap kemampuan keterampilan produktif berbahasa Inggris siswa. Hasil penelitian menunjukkan bahwa ada beberapa strategi yang digunakan oleh dosen dalam mengajarkan keterampilan produktif bahasa Inggris pada program studi pendidikan bahasa Inggris FKIP UIR, yaitu: (1) di kelas berbicara; Buzz Grup, Think-Pair-Share, Circle of Voices, Video Recording Method. (2) di kelas Menulis; Collaborative Writing Technique. Strategi-strategi tersebut cocok untuk pengajaran berbicara atau menulis serta dapat memberi gambaran kepada pembaca untuk meningkatkan kemampuan produktif bahasa Inggris siswa.

Kata Kunci: strategi mengajar, keterampilan produktif dalam bahasa inggris

\section{INTRODUCTION}

The purpose of English teaching and learning is to improve the students' four skills of Speaking, Reading, Writing, and Listening. Speaking and writing or productive skill is an important skill in language because the goal of learning language is to develop proficiency in English both spoken and written efficiency. By English productive skill, people can convey and give information and ideas, and maintain social relationship by communicating with others. Especially in globalization era, English productive skills is very important, because we cannot imagine how if we meet different people from the other countries and we cannot make a conversation with them, English can help us to make a conversation both spoken and written because it is an international language.

Teaching speaking is considered to become the most difficult lesson, the students need to measter pronunciation, structure, discourse and the social context of cultural competence. Besides, speaking is difficult, more effort is required on the part of the students and lecturers. It is not enough for the students to listen only. And writing as important as it is suffers in both the depth of concentration a lecturer allots to it in the classroom, and the quality produced by the students as a result. It is important to encourage students to write as much as possible. To increase quality and accuracy, lecturers need to ensure that they are consistent in enforcing writing rules and in correcting students' written work.

This research explored the strategies used by the lecturers in developing students' cognitive academic language proficiency by working on students' English productive skill. This study will investigate lecturer behaviors, lesson delivery and sequence of content and learning expectations used by lecturers in teaching English productive skills at English study program of teacher training and education faculty of Islamic university of Riau. 


\subsection{The Nature of Productive Skills}

The productive skills are speaking and writing, because learners need to articulate words and write to produce language. Learners receive language by listening to conversation, music, and video and also by reading comprehension, newspaper, poem, book, etc. Then they move on to Productive Skills: Speaking is an oral production of language. McDonough and Shaw (2003) stated that, speaking involves expressing ideas and opinions, expressing a wish or desire to do something, negotiating or solving problems or establishing and maintaining social relations. So, speaking is the oral process to produce language. On the other hand, writing is a productive skill in written mode. When someone talks about writing there is usually two-way distinction of writing: institutional and personal writing. Institutional writing includes textbooks, reports, applications, business correspondence whereas personal writing covers personal letters and creative writing.

\subsection{Speaking Skill}

Ur (1991) said that speaking is the productive aural/oral skill. It consists of producing systematic verbal utterance to convey meaning. According to Gower, Philips and Walters (1995) every opportunity for speaking in classroom should be taken. It can be done by trying to communicate that students realize their need for language and by speaking that they increase their fluency and confidence. At first students may be self-conscious and reluctant to speak in front of people. However, there are ways (repetition work and pair work activities) of providing a safer, less public environment in which the students can begin to practice speaking. As a productive skill speaking is very important. Previously speaking was not a popular activity to practice in the classrooms. But nowadays the process of speaking activity has changed a lot. Teachers now try to encourage the students to improve students' communication skills through speaking.

According to Nunan (1989), to be successful in acquiring the speaking skill in the target language, the following sub skills should be developed:

1. The ability to articulate phonological features of the language comprehensively.

2. Expertise on stress, rhythm, intonation patterns.

3. An acceptance degree of fluency.

4. Transactional and interpersonal skills.

5. Skills in talking short and long speaking turns.

6. Skills in the management of interaction.

7. Using appropriate formulae and fillers.

\subsection{Teaching Speaking}

Teaching speaking needs strategies and also roles; a teacher must have a good role in order that the students get more information from the materials and also get understood anymore.

According Harmer (2005), there are three suggestions if we are trying to get students to speak fluently:

1) Prompter 
Students sometimes get lost, cannot thing of what to say next, or in some other way lose the fluency we expect to them. We can leave them or struggle out of such situation on their own, and indeed sometimes this may be the best option. However, we may be able to help them and the activity to progress by offering discrete suggestions. If this can be done supportively without disrupting the discussion, or forcing students out, it will stop sense of frustration that some students feel when they come to a dead end of language or ideas.

\section{2) Participant}

Teacher should be good animators while asking students to produce a language. Sometimes this can be achieved by setting up an activity clear and with enthusiasm. At other times, however, teachers may want to participate in discussion themselves. That way can prompt covertly, introduce new information to help the activity along, ensure continuing students engagement, and generally maintain a creative atmosphere.

3) Feedback provider

The vexed question of when and how to give feedback in speaking activities in answered by considering carefully the effects of possible different approach.

\subsection{Writing Skill}

Writing is a specific skill which helps people to put their thoughts into words in a meaningful form through pen and paper. According to Grossmann (2009), Writing can take many forms, including anything from a shopping list, acting as an aide-memoire, through letters, both formal and informal, to academic texts like this essay. Harmer (1998) noted that, writing is a basic skill, students should know how to write letters, how to put reports together. Moreover, they should know how to write using electronic media. So, Harmer (1998) emphasized writing as important as speaking, listening and reading. Writing displays a variety of features which can be observed within the sentence at the level of grammar, and beyond the sentence at the level of text structure (Nunan, 1999). Halliday (1985) outlined 3 main purposes for writing, namely "action" (including public signs), "information" (including newspapers and magazines etc) and "entertainment" (including comic strips, novels, newspaper features etc) (as cited in Nunan, 1999).

\subsection{Teaching Writing}

Teaching how to write effectively is one of the most important life-long skills lecturers impart to their students. When teaching writing, lecturers must be sure to select resources and support materials that not only aid them in teaching how to write, but that will also be the most effective in helping their students learn to write.

According to McDonough and Shaw (2003), the classroom can provide an environment for writing at each of the three main stages;

1. Gathering ideas: pre-writing

2. Working on drafts

3. Preparing the final version.

To describe the classroom environment they said that the classroom can be structured in such a way as to provide positive intervention and support in the 
development of writing skills. Scrivener (2011) discussed planning classroom writing works. The teacher can help the students to choose the topic; choose a genre; select ideas; discuss ideas with others to get new perspectives; select, sequence and organize ideas, find grammar and lexis suitable for text and gradually to write the final version. As he said that, Writing involves different kind of mental process. In teaching writing, there are so many ways that can be offered to educators a number of resources that assist in teaching writing.

\section{METHOD}

This research is a descriptive qualitative research. It consist of only one variable, which the researcher want to explore the description of strategies used by the lcturers and its influences on students' English productive skill at English study program of FKIP UIR. The purpose of this study is describing the strategies used by the lecturer and exploring those strategies on students' English productive skills. Thus the research participants in this study are the lecturers who tought writing and speaking, there were 2 lecturers and second semester students at English Study Program of FKIP UIR, there were 30 participants.

Qualitative research is a type of educational research in which the researcher relies on the views of participants; asks board, general questions; collects data consisting largely of words (or text) from participants; describes and analyzes these words for themes; and conducts the inquiry in a subjective, biased manner (Creswell, 2008:46).
The instruments of this research are observation, interview and documentation. The obsevation were done to see the teaching athmosphere while teaching and learning process in the classroom. The researcher interviewed the lecturers about the startaegies, the implementation of strategy used and its influences on students' English productive skills. McNamara (1999) said that interview are particularly useful for getting the story behind a participants' experiences. The interviewer can pursue in-depth information around the topic. Interviews may be useful as follow-up to certain respondents to questionaires, e.g, to further investigate their response. The last instruments is documentation. The researcher took a picture and video while teaching and learning to support the data. Documentation were taken in order to record at the moment of students at English study program of FKIP UIR while studying English productive skills.

\section{FINDING AND DISCUSSION}

The researcher had found from the interview with the lecturers about the teaching strategies used in teaching English productive skills at English study program of FKIP UIR. The speaking lecturers used some strategies in the classroom such as; Buzz Group, think-pair-share, circle of voices, and video recording method. And writing lecturer used collaborative teaching technique. These strategies felt effective to achieve the productive skills of the students during teaching and learning in the classroom. 


\subsection{Strategies in Teaching Speaking}

These are four teaching strategies used by lecturers in the speaking for group activities classroom, they are:

\section{a. Buzz Group}

One of strategies recently used by lecturers in teaching speaking is buzz groups. It involves members engaging in short, informal discussions, giving responses to a particular sentence starter, topic or question. This strategy arranges members to discuss any difficulties understanding, issues, topics, current problems, answer prepared questions, define or give example of key concepts, or speculate things. This strategy is very flexible to use for every kind of discussion group, it is easy to implement in any size of classroom. The members are easily to communicate each other through listening and undersatnding the others' thoughts and ideas and then giving comments and feedbacks.

Barkley (2005) said that Buzz Groups are teams of four to six students that are formed quickly and extemporaneously to respond to course-related questions. Each group can respond to one or more questions; all groups can discuss the same or different questions. Discussion is informal, and students do not need to arrive at consensus, but simply exchange ideas. Typically, Buzz Groups serve as a warm-up to wholeclass discussion. They are effective for generating information and ideas in a short period of time. By dividing a whole class into small groups, more students have had a chance to practice their comments and to increase their repertoire of ideas in the Buzz Group, in the whole class discussion that follows is often richer and more participatory.

The buzz group was used while teaching and learning process in the treatment. The purpose is to know the effectivenes of buzz group in teaching speaking. In the teaching and learning process, the writer applied and taught the teaching process based on the lesson plan. The procedure of teaching speaking by using buzz group as stated by Barkley (2005):

1. Form groups; announce the discussion prompts and time limit.

2. Ask group members to exchange ideas in response to the prompts.

3. Check periodically to see whether groups are still actively engaged and focused on the assigned topic. If off topic, shorten the time limit. If on topic and the time has ended, consider extending the limit for a few minutes.

4. Ask the students to return to whole-class discussion and restate the prompt to begin.

Based on observation, the researcher concludes that the study of using Buzz group to improve the students' speaking skill is successful for some points.

1. The use of buzz group enables to the students to improve their vocabularies.

2. The use of Buzz group increased the students' mastery on English grammar through the activities of preparing the written descriptive text for speaking. They prepared the written descriptive text then memorized and told it to their friends. They learnt the grammar in detail and tried to find the meaning of the words in dictionary. They, of 
course, learnt the basic theory of grammar and found new references in doing the task for presentation.

3. The use of Buzz group enables the students to improve their speaking skills, vocabulary, grammatical, pronunciations, fluency and content. The improvement can be obtained from practicing and doing the instructions which have been stated in the pictures which can be found in the laboratory. Although the instructions, first, are given orally by the teacher, the students are instructed to memorized and to imitate him to give instructions to their friends. In short, by memorizing, pronouncing, imitating, and giving instructions to their friends, the students are easy to express their ideas, exposed the ideas organized and systematically understanable. Buzz Group helped students' speaking performance better. Moreover, the students could explore the text in group and individual into a presentation.

\section{b. Think-Pair-Share}

The researcher found the second strategy used by lecturer in teaching speaking is Think-PairShare. This startegy as an interesting startegy which encourage members to think and share their thought. It has three steps; first, members think individually about a particular question, topic or scenario, then they pair up to discuss and compare their ideas. Finally, they are given the chance to share their ideas in a large class discussion.

The think-pair-share startegy is a strategy designed to provide students to think a given topic by enabling them to formulate individual ideas and share these ideas with another students. This strategy ia a learning strategy to encourage students classroom participation. The think-pair-share strategy is a cooperative discussion srategy to help students work in group. In applying this strategy, the lecturer poses a question, preferable one demanding analysis, evaluation, or synthesis and give students about a minuteto think through an appropriate response (Lyman, 1987). The students can share their ideas that appear in their mind as the responses to the lecturers' questions in the teaching and learning process. Students then turn to a partner and share their responses with others.

Think-Pair-Share forces strictly all members to attempt an initial response to the question, topic or scenario which they can clarify and expand as they collaborate in a small group. It also gives them a chance to validate their ideas in a small group before mentioning them to a larger group, which may help members to be more confidents delivering their ideas.

From the result of observation, While implementing this strategy, the lecturer divided the students into group of two. Each group was posed with some questions to be shared with their pairs about the topics in terms of the material from the lecturer. Students shared the topics in their own pairs and then presented to the whole class. in the process of the implementing the strategy, lecturer gave students think time and directed them to think on their own about the question. Following the think time, students 
turn to face their learning partner and work together, sharing ideas, discussing, clarifying and challenging. The lecturer then asked the students to pair with their partner and shared class. it is important that students need to be able to share their partner's idea as well as their own. The lecturer then call on a few students to share their ideas with the rest of the class.

\section{c. Circle of Voices}

This method involves members taking turns to speak. Members from small group circle of two or three. Give them a topic and allow them a few minutes to organize their thought and ideas about it. Then the discussion begins with each member having up to three minutes of uninterrupted time to speak. During this time, no one else is allowed to say anything. After everyone has spoken once, the small group circles back to a big group for general discussion.

Some shy member might feel uncomfortable having to speak. A variation to this method, which encourages members to listen more carefully to each other, involves requiring each person to begin by paraphrasing the comments of the previous member or by showing how his or her remarks relate to those of the previous member. For this variation, students will need less preparation time before the circle begins, but they may need more time between speakers.

This method is very suitable for big number of members joining the discussion, where the lecturer has to think creatively to involve everyone have a time to speak during the discussion. The small group circles formation is the first step of shouting their voice, everyone will shout in abig circle group formation and everybody can deliver their thought about the topic given. Some leaders of discussion group initially use the circle of voice method when they find out few students are quite shy or afraid to speak in front of the others. Through this method, the leader could manage the shyness of members by dividing them into groups and let them to talk to their group friends.

Circle of voices are characterized by the use of a talking piece, which regulates communication. Both speaking and listening are important in the circle because mutual understanding lays the groundwork for deeper, more meaningful discussion. Circle of voices can be used for discussion, problem solving and decision making. The basic purpose of talking circle is to create a safe, non-judgmental place where each participant has the opportunity to contribute to the discussion of difficult and important issues.

The final part of the talking circle provides time for participants to reflects on the ideas and contributions of themselves and the other participants. Lecturter asked questions that help the students identify what they have learned during circle. Sometimes, lecturer asked students to express appreciation to another students to share something they learned from participating in the talking circle or lecturer may ask them to consider all that was said in the talking circle and gave themselves a specific piece of 
advice for the future based on it. Another option lecturer have used is to share a difference and similarity they have discovered between themselves and others in the group.

\section{d. Video Recording Method}

The resercher found the last teaching strategy used by lecturer is video recording method. The existence of technology as an integral part in students' lives today, the lecturer used video recorded task for trigging up students speaking skill. The process of video making enable students to activate their target language without excessive anxiety because they have enough rehearsal and doing it outside the class, even they can develop critical thinking and organization of idea. Also, it provides more time to expose speaking which is limited in the classroom. The authenticity is also high because the students have short presentation about two or three minutes to talk based on topic they choose but still relates to the main topic they learn in thye class. This task encourage students to speak because it becomes one of part in assessment. In addition, recording video through mobile phone is easy to do, even some mobile phone has provided high resolution camera and video editor.

According to Michael (2010) there are some positive relation of the use of video recording to some principle of teaching English:

a. the use of video production can involve communicative activity such as problem solving and role play.

b. It provides opportunity to use target language in authentic and meaningful setting. c. It lets students to express their ideas and opinions

d. The process of video making will enable students to activate their target language without excessive anxiety because they will have enough rehearsal and doing it outside the class even they can develop critical thinking and organization of idea.

e. Also it provides more time to expose speaking which is limited in the classroom.

From the observation, the researcher found that the lecturer explained the regulation, the duration of making video, the topic and aspect of speaking would be assessed. It is intended to build students' understanding in the task. Then, the lecturer showed an example of the task. The example can be the video of native speaker so that the students can have the target model of English.

Furthemore, the students make the video with the certain topic. It is highly recommended to use topic related to the teaching and learning topic in class or students' experience. Therefore, the use of video can be authentic speaking training. After students complete the video teacher needs to give feedback to the students' performance. Hence, the students understand their speaking strength and weakness. In addition, the number of video created by students can be adjusted to the meeting or the duration of teaching and learning process.

The students stated that the video recording task helped them to practice speaking, to explore their speaking skill without feeling ashamed, to provide enough time to 
speak, to explore their ideas, to know their ability in speaking, and to express their idea with good arrangement of material and vocabulary, to improve their confidence, to remake the video when they made mistake, to understand new words and the way to pronounce the words, to have new experience in learning English and to train their discipline.

\subsection{Strategies in Teaching Writing}

Teaching strategies used by lecturers in essay writing classroom is only using collaborative writing technique.

\section{a. Collaborative Writing}

In collaborative writing, student pairs or triads write a formal paper together. Each student contributes at each stage of the writing process: brainstorming ideas; gathering and organizing information; and drafting, revising and editing the writing. Working together can help students to learn and perform the stages of writing more effectively. Additionally, students typically write better and take more pride in their writing when they are writing for an audience.

The teaching procedure by using this technique that had been done by lecturer are as follow:

- Students form pairs by choosing partners and then generate ideas by brainstorming together or conducting preliminary research.

- Together, students organize their ideas and create an outline.

- Students divide up the outline, selecting or assigning sections for each student to write initial drafts individually.
- Teams read first drafts and discuss and resolve any significant disparities in voice, content, and style.

- Teams combine individual sections into a single document.

- Teams revise and edit their work, checking for content and clarity as well as grammar, spelling and punctuation.

- After the final edit, teams submit their papers to the lecturer for assessment and evaluation.

Collaborative writing is challenging, consider preparing students by having them engage in simpler collaborative work earlier in the semester. Also, if students have not had much writing experience, lecturer may wish to have them individually complete smaller writing assignment first. Writing is not an easy task, and collaborative writing is particularly difficult. Encourage students to proofread beyond a wordby-word level and review at the level of sentences, paragraph, and whole section.

\section{CONCLUSION}

The result of this research showed that there were some strategies used by lecturer in teaching speaking and writing, they are:

1. Buzz Gorup. The researcher concludes that the study of using Buzz group to improve the students' speaking skill is successful for some points. The use of buzz group enables to the students to improve their vocabularies. The use of Buzz group increased the students' mastery on English grammar through the activities of preparing the written descriptive text for 
speaking. The use of Buzz group enables the students to improve their speaking skills, vocabulary, grammatical, pronunciations, fluency and content. Buzz Group helped students' speaking performance better.

2. Think-Pair-Share. This method has a quite significant improvement to the knowledge of students which improved their personal speaking skill. It also gave them a chance to validate their ideas in a small group before mentioning them to a larger group which may help students to be more confidents to deliver their ideas.

3. Circle of Voices. This method is suitable for big number of students joining the class. It helped the students in speaking, by circle of voices, the students must do the work beforehend and have more opportunity to talk.

4. Video Recording Method. By implementing this method, lecturer can increase students' speaking skill. The students stated that the video recorded task provided chance to speak without feeling ashamed, helped to make good arrengement of speaking material and vocabulary, and gave new experience in learning English. Finally, this method was effective in increasing students' speaking skill.

5. Collaborative writing technique. Writing collaboratively can help prevent the academic dishonesty some times associated with the conventional term paper assignment. Also, since the group follows the procedural steps working within a specific time frame, students cannot simply copy a paper from another source.

\section{REFERENCES}

Alvaradorico, J. L. (2014). Identifying Factors Causing Difficulties to Productive Skills Among Foreign Language Learners. Open Writing Doors Journal. Vol.11. No.1: 65-86.

Badger, R.G. and G. White (2000). A Process Genre Approach to Teaching Writing. ELT journal 54(2): 153-60.

Brown, H. Douglas. (2000). Principles of Language and Teaching. (Third Edition). New Jersey: Prentice Hall.

Cameron, (2001). Teaching Languages to Young Learners. Cambridge. Cambridge University Press.

Canale, M \& Swain, M. (1980). Theoretical Bases of Communication Approaches to Second Language Teaching and Testing. Applied linguistic, 1,147.

Creswell, J. W. (2002). Educational Research: Planning, Conducting, and Evaluating Quantitative and Qualitative Research. Upper Saddle River, NJ: Pearson.

Creswell, J. W. (2005). Educational Research: Planning, Conducting, and Evaluating Quantitative and Qualitative Research. Upper Saddle River, NJ: Pearson. 
Cyril, J. (1988). Communicative Language Testing. New York: Prentice Hall.

Gaffield-Vile, (1998). Creative Writing in the English Langauge Teaching Classroom. Los Angeles.

Golkova, D. (2014). Productive Skills in Second Language Learning. Procedia - Social and Behavioral Sciences 143447 481. Available online at www.sciencedirect.com.

Gower, R. (1995). Teaching Practice Handbook. Oxford: Hainemann.

Grahem, S. and Harris, K. (2000). Writing Better: Effective Strategies for Teaching Students with Learning Difficulties. Brookes Publishing.

Grossmann, P. (2009. Redefining Teaching, Re-imagining Teacher Education. Theory and Practice. 15(2). 273-289.

Halliday, M.A.K. (1985). Intrduction to Functional Grammar. London: Arnold.

Harmer, J. (2007). The Practice of English Language Teaching. England: Longman.

Hughes, A. (2003). Testing for Language Teachers. Cambridge: Cambridge University Press.

McDonough, J and Shaw, C. (2003). Materials and Methods in ELT:
A teacher's Guide. 2nd Publishing. Oxford; Blackwell publishers.

Nunan, David. (1989). Language Teaching Methodology. Macquarie University.

Oczkus, L. (2007). Guided Writing: Practical Lessons, Powerful Results. Los Angeles; California.

Philips, D. and Walters, S. (1995). Teaching Practice Handbook. Handbooks for the English Classroom Series. Cambridge: Heinemann.

Richards and Rodgers, T. S. (1976). Approaches and Methods in Language Teaching: A Description and Analysis. Cambridge: Cambridge University Press.

River, W. (1987). Interactive Language Teaching. Cambridge: Cambridge University Press.

Scrivener, J. (2011). Learning Teaching. The Essential Guide to English Language Teaching: 3rd Edition. Macmillan education.

Tribble, C. (1996). Writing. Oxford: Oxford University Press.

Ur, Penny. (1991). A Course in Language Teaching Practice and Theory. Cambridge: Cambridge University Press. 